Article

\title{
Esculetin as a Bifunctional Antioxidant Prevents and Counteracts the Oxidative Stress and Neuronal Death Induced by Amyloid Protein in SH-SY5Y Cells
}

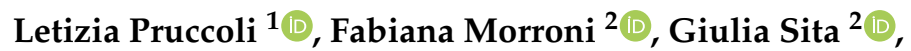 \\ Patrizia Hrelia ${ }^{2}$ (D) and Andrea Tarozzi ${ }^{1, *(D)}$ \\ 1 Department for Life Quality Studies, Alma Mater Studiorum-University of Bologna, Corso d'Augusto 237, \\ 47921 Rimini, Italy; letizia.pruccoli2@unibo.it \\ 2 Department of Pharmacy and Biotechnology, Alma Mater Studiorum-University of Bologna, Via Irnerio 48, \\ 40126 Bologna, Italy; fabiana.morroni@unibo.it (F.M.); giulia.sita2@unibo.it (G.S.); \\ patrizia.hrelia@unibo.it (P.H.) \\ * Correspondence: andrea.tarozzi@unibo.it; Tel.: +39-0541434620
}

Received: 15 May 2020; Accepted: 23 June 2020; Published: 25 June 2020

check for updates

\begin{abstract}
Oxidative stress (OS) appears to be an important determinant during the different stages of progression of Alzheimer's Disease (AD). In particular, impaired antioxidant defense mechanisms, such as the decrease of glutathione (GSH) and nuclear factor erythroid 2 (NF-E2)-related factor 2 (Nrf2), a master regulator of antioxidant genes, including those for GSH, are associated with OS in the human AD brain. Among the neuropathological hallmarks of AD, the soluble oligomers of amyloid beta $(A \beta)$ peptides seem to promote neuronal death through mitochondrial dysfunction and OS. In this regard, bifunctional antioxidants can exert a dual neuroprotective role by scavenging reactive oxygen species (ROS) directly and concomitant induction of antioxidant genes. In this study, among natural coumarins (esculetin, scopoletin, fraxetin and daphnetin), we demonstrated the ability of esculetin (ESC) to prevent and counteract ROS formation in neuronal SH-SY5Y cells, suggesting its profile as a bifunctional antioxidant. In particular, ESC increased the resistance of the SH-SY5Y cells against OS through the activation of Nrf2 and increase of GSH. In similar experimental conditions, ESC could also protect the SH-SY5Y cells from the OS and neuronal death evoked by oligomers of A $\beta_{1-42}$ peptides. Further, the use of the inhibitors PD98059 and LY294002 also showed that Erk1/2 and Akt signaling pathways were involved in the neuroprotection mediated by ESC. These results encourage further research in AD models to explore the efficacy and safety profile of ESC as a novel neuroprotective agent.
\end{abstract}

Keywords: amyloid beta; oxidative stress; neuronal death; esculetin; bifunctional antioxidants

\section{Introduction}

Several studies suggest that oxidative stress (OS) is an early event in the pathogenesis of Alzheimer's disease (AD) [1,2]. OS also appears to be an important determinant during the different stages of progression of AD [3]. In this context, it is likely that a causal relationship occurs between OS and several neuropathological hallmarks of AD, including amyloid plaques containing amyloid beta $(A \beta)$ peptides and neurofibrillary tangles at an extra- and intra-cellular level, respectively [4]. Among the different forms of $A \beta$ peptides, the soluble $A \beta_{1-42}$ peptides or shorter fragments seem to promote OS through their interaction with redox-active metals [5]. A $\beta$ may further contribute to 
OS by triggering $\mathrm{N}$-methyl-D-aspartate receptor-dependent $\mathrm{Ca}^{2+}$ influxes leading to mitochondrial dysfunction with generation of reactive oxygen species (ROS) and subsequent neuronal death [4].

High $\mathrm{OS}$ in $\mathrm{AD}$ and its prodromal stage, mild cognitive impairment, have been presumed to also be a consequence of compromised antioxidant defense mechanisms in both the blood and brain [6]. Several studies record that the decrease of glutathione (GSH) and GSH synthetase involved in GSH synthesis in the hippocampus and frontal cortex are associated with development of AD pathology $[7,8]$. These alterations of redox homeostasis are consistent with decreased levels of nuclear factor erythroid 2 (NF-E2)-related factor 2 (Nrf2), a master regulator of antioxidant defense and detoxification genes activated by OS conditions, in hippocampal neurons of human AD brain [9]. More recent studies suggest that the maintenance of redox homeostasis by Nrf2 is able to prevent not only OS but also inflammation, a critical process in the pathogenesis of neurodegenerative diseases, in in vitro and in vivo neuroinflammation models [10]. In particular, Nrf2 represses the inflammatory responses mediated by nitric oxide synthase, interleukin-6, tumor necrosis factor- $\alpha$. Nrf2 responds differently to ROS generated during acute and chronic OS. In particular, during chronic OS frequently detected in aging and in $\mathrm{AD}$, the Nrf2 pathway becomes unresponsive to ROS [10,11]. Hence, the interplay between Nrf2 activation and chronic OS suggests neuroprotective strategies using an association of compounds that can either activate the Nrf2 pathway by ROS independent mechanisms or act directly as ROS scavenger compounds that may thus be required to reduce OS in AD [12]. In this regard, several bifunctional antioxidants, such as lipoic acid, curcumoids, chalcones, polyenes, and phenolic Michael acceptors can exert the ability both to scavenge oxidants directly (i.e., direct antioxidant activity) and to induce the expression of cytoprotective phase 2 genes which have different antioxidant actions (i.e., indirect antioxidant activity) [13].

Coumarins are a class of phenolic compounds found in several medicinal plants, for example Cichorium intybus, Artemesia capillaris, Ceratostigma willmottianum and Citrus limonia [14,15]. Among the coumarins, esculetin, ESC (6,7-dihydroxycoumarin) has been shown to have interesting pharmacological actions in dysmetabolic syndromes, cardiovascular diseases, renal dysfunctions, cancer and neurological disorders [16]. In this context, recent studies showed the ability of ESC to prevent and counteract OS, mitochondrial dysfunction, inflammation and neuronal death, in different animal models of psychiatric disorders, cerebral ischemia and Parkinson's disease [17-21]. Taken together, these studies highlight the ability of ESC to cross the blood-brain barrier (BBB) and to exert neuroprotective effects at the brain level against several pathological conditions. However, the potential antioxidant and neuroprotective effects of ESC against neurodegenerative events associated with AD still remain unanswered.

In this study, we evaluated the ability of ESC to prevent and counteract OS as well as the neuronal death elicited by oligomers of $A \beta_{1-42}$ peptides $\left(O A \beta_{1-42}\right)$, soluble aggregates of $A \beta$ peptides involved in the pathogenesis of AD, in neuronal SH-SY5Y cells. In particular, we initially assessed the antioxidant effects of ESC together with other natural coumarins, including scopoletin (SCOP), fraxetin (FRAX) and daphnetin (DAPH), that show a similar chemical structure (Figure 1), in order to also evaluate the relationship between the chemical structure of these coumarins and the direct and indirect antioxidant properties at neuronal levels. The experimental approach was thus characterized by different treatments of SH-SY5Y cells with ESC, before or during the neuronal damage evoked by $\mathrm{OA} \beta_{1-42}$, to appraise the ability of ESC to prevent or counteract pathogenic events of AD.

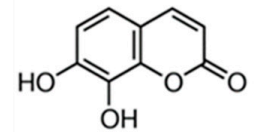

Esculetin (6,7-Dihydroxycoumarin)

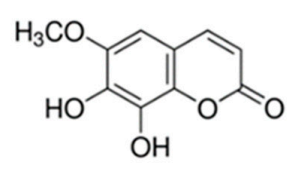

Scopoletin (7-Hydroxy-6methoxycoumarin)<smiles>COc1cc2ccc(=O)oc2cc1O</smiles>

Fraxetin (7,8-Dihydroxy-6methoxycoumarin)<smiles>O=c1ccc2cc(O)c(O)cc2o1</smiles>

Daphnetin

(7,8-Dihydroxycoumarin)

Figure 1. Chemical structure of coumarins. 


\section{Materials and Methods}

\subsection{Chemicals}

The coumarins ESC (purity: $\geq 98 \%$ ), SCOP ( $\geq 99 \%)$, FRAX ( $\geq 98 \%$ ) and DAPH ( $\geq 97 \%), 2,2^{\prime}$-Azino-bis (3-ethylbenzothiazoline-6-sulfonic acid) diammonium salt (ABTS), 2', $7^{\prime}$-dichlorodihydrofluorescein diacetate (DCFH-DA), tert-butyl hydroperoxide solution $(t-\mathrm{BuOOH})$, monochlorobimane (MCB), dihydroethidium (DHE), 3-(4,5-dimethyl-2-thiazolyl)-2,5-diphenyl-2H-tetrazolium bromide (MTT), 2,2-diphenyl-1-picrylhydrazyl (DPPH), propidium iodide (PI), PD98059 (PD), DL-Buthionine-(S,R)-sulfoximine (BSO) and anti- $\beta$-actin antibody were purchased from Sigma-Aldrich (Sigma-Aldrich, St. Louis, MO, USA). LY294002 (LY) was purchased from Alexis Biochemicals (Alexis Biochemicals, San Diego, CA, USA). The Nrf2 antibody was purchased from Santa Cruz (Santa Cruz Biotecnology, Dallas, TX, USA). Akt (serine-threonine kinase), Phospho-Akt, Erk1/2 (extracellular signal-regulated kinase), Phospho-Erk1/2, GSK3 $\beta$ (glycogen synthase kinase-3 $\beta$ ), Phospho-GSK3 $\beta$ and Lamin B1 antibodies were purchased from Cell Signaling (Cell Signaling Technology, Danvers, MA, USA). Beta-Amyloid (1-42) peptide was purchased from AnaSpec (AnaSpec, Fremont, CA, USA). The Nuclear Extract and TransAM Nrf2 Kit were purchased from Active Motif (Active Motif, Carlsbad, CA, USA). All chemicals used were of high purity analytical grade.

\subsection{Cell Culture and Preparation of Coumarin Solutions}

Human neuronal SH-SY5Y cells were purchased from the Lombardy and Emilia Romagna Experimental Zootechnic Institute (Italy). SH-SY5Y cells were routinely grown in Dulbecco's modified Eagle Medium with phenol red supplemented with $10 \%$ fetal bovine serum, $2 \mathrm{mM} \mathrm{L-glutamine,}$ $50 \mathrm{U} / \mathrm{mL}$ penicillin and $50 \mu \mathrm{g} / \mathrm{mL}$ streptomycin at $37{ }^{\circ} \mathrm{C}$ in a humidified incubator with $5 \% \mathrm{CO}_{2}$. For the experiments with SH-SY5Y cells, stock coumarin solutions were prepared in dimethyl sulfoxide (DMSO) at $20 \mathrm{mM}$. The stock solutions were further diluted in complete medium to obtain the desired concentrations of coumarins in a maximum of $0.1 \%$ DMSO.

\subsection{Determination of Neuronal Viability}

The neuronal viability was evaluated by the reduction of MTT to its insoluble formazan, as previously described [22]. Briefly, SH-SY5Y cells were seeded in a 96 well plate at $2 \times 10^{4}$ cells/well, incubated for $24 \mathrm{~h}$ and subsequently treated with various concentrations of the studied coumarins $(2.5-80 \mu \mathrm{M})$ for $24 \mathrm{~h}$ at $37^{\circ} \mathrm{C}$ in $5 \% \mathrm{CO}_{2}$. The treatment medium was then replaced with MTT in Hank's Balanced Salt Solution (HBSS) $(0.5 \mathrm{mg} / \mathrm{mL})$ for $2 \mathrm{~h}$ at $37^{\circ} \mathrm{C}$ in $5 \% \mathrm{CO}_{2}$. After washing with HBSS, formazan crystals were solubilized in isopropanol. The amount of formazan was determined (570 nm, reference filter $690 \mathrm{~nm}$ ) using the multilabel plate reader VICTOR ${ }^{\mathrm{TM}}$ X3 (PerkinElmer, Waltham, MA, USA). Data are expressed as percentage relative to untreated cells.

\subsection{Determination of Intrinsic Antioxidant Activity}

The intrinsic antioxidant activity of coumarins was determined using DPPH and ABTS radicals. The DPPH assay was performed as previously described in [23]. Briefly, $150 \mu \mathrm{L}$ of DPPH in ethanol $(100 \mu \mathrm{M})$ was added to $50 \mu \mathrm{L}$ of coumarins at different concentrations $(2.5-40 \mu \mathrm{M})$ in a 96 well plate. After $30 \mathrm{~min}$ of incubation, the absorbance of the reaction solution was measured at $490 \mathrm{~nm}$ using the multilabel plate reader VICTOR ${ }^{\text {TM }}$ X3 (PerkinElmer, Waltham, MA, USA).

The ABTS assay was performed as previously described in [24]. Briefly, ABTS radical was generated by mixing a $2 \mathrm{mM}$ ABTS solution with $7 \mathrm{mM}$ potassium persulfate $\left(\mathrm{K}_{2} \mathrm{~S}_{2} \mathrm{O}_{8}\right)$ and incubating in the dark for $24 \mathrm{~h}$ at room temperature. Before use, the ABTS solution was diluted (1-25 mL of phosphate buffered saline) to obtain an absorbance value of $0.70 \pm 0.02$ at $734 \mathrm{~nm}$. Upon addition of $1 \mathrm{~mL}$ of the diluted ABTS solution to $10 \mu \mathrm{L}$ of the studied coumarins at different concentrations $(2.5-40 \mu \mathrm{M})$, the absorbance at $734 \mathrm{~nm}$ was recorded after $1 \mathrm{~min}$. The antioxidant activity was expressed as a concentration of coumarin able to decolorize $50 \%$ of the ABTS radical. 


\subsection{Determination of Direct and Indirect Antioxidant Activity}

The direct and indirect antioxidant activity of coumarins was assessed in SH-SY5Y cells as previously described in [25]. Briefly, SH-SY5Y cells were seeded in a 96 well plate at $2 \times 10^{4}$ cells/well, incubated for $24 \mathrm{~h}$ and subsequently treated with coumarins at different concentrations $(2.5-20 \mu \mathrm{M})$ for $2,6,12$ and $24 \mathrm{~h}$ at $37{ }^{\circ} \mathrm{C}$ in $5 \% \mathrm{CO}_{2}$. The treatment medium was then discarded and $100 \mu \mathrm{L}$ of the fluorescent probe DCFH-DA in phosphate buffered saline $(10 \mathrm{~g} / \mathrm{mL})$ was added to each well. After 30 min of incubation at room temperature, the DCFH-DA solution was replaced with $100 \mu \mathrm{L}$ of $t$-BuOOH $(200 \mu \mathrm{M})$. After further $30 \mathrm{~min}$, the ROS formation was measured (excitation at $485 \mathrm{~nm}$ and emission at $535 \mathrm{~nm}$ ) using the multilabel plate reader VICTOR ${ }^{\mathrm{TM}}$ X3 (PerkinElmer, Waltham, MA, USA). Data are expressed as fold increases in ROS formation evoked by $t$-BuOOH.

\subsection{Determination of Antioxidant Coumarins in Membrane and Cytosolic Fractions}

The cellular uptake was determined indirectly by using the ABTS assay, as previously described in [26]. Briefly, SH-SY5Y cells were seeded in $60 \mathrm{~mm}$ dishes at $2 \times 10^{6}$ cells/dish, incubated for $24 \mathrm{~h}$ and subsequently treated with ESC and DAPH $(20 \mu \mathrm{M})$ for $2 \mathrm{~h}$ at $37{ }^{\circ} \mathrm{C}$ in $5 \% \mathrm{CO}_{2}$. At the end of incubation, cells were washed 3 times with cold phosphate buffered saline (PBS) and removed from the dish by gently scraping with a cell lifter. Cells were then collected in $1 \mathrm{~mL}$ of PBS and centrifuged at 10,000 rpm for $10 \mathrm{~min}$ at $4{ }^{\circ} \mathrm{C}$. The supernatant was removed, and cells were washed with $1 \mathrm{~mL}$ of PBS. This was repeated a further 2 times and the pellet was finally reconstituted in $600 \mu \mathrm{L}$ of lysis buffer containing Triton X-100 0.05\%. Cells were then homogenized and allowed to stand at $4{ }^{\circ} \mathrm{C}$ for $30 \mathrm{~min}$. The cytosolic fraction was obtained by centrifugation at 14,000 rpm for $15 \mathrm{~min}$ at $4{ }^{\circ} \mathrm{C}$. The remaining pellet was solubilized in $400 \mu \mathrm{L}$ of lysis buffer containing Triton X-100 $1 \%$ to obtain the membrane fraction. Cytosolic and membrane fractions were stored at $-20{ }^{\circ} \mathrm{C}$. Small amounts were removed for the determination of the protein concentration according to the Bradford method. The antioxidant activity of coumarins was then measured on cytosolic and membrane fractions using the ABTS assay. The final total antioxidant activity (TAA) of cytosolic and membrane fractions was calculated by comparing ABTS decolorization with that of a standard curve of Trolox, a water-soluble analog of vitamin E. The standard curve was prepared using Trolox in a range of concentrations from 50 to $150 \mu \mathrm{M}$. Data are expressed as micromole of Trolox equivalent antioxidant activity per milligram of protein ( $\mu \mathrm{molTE} / \mathrm{mg}$ protein).

\subsection{Determination of GSH Levels}

GSH levels were assessed in SH-SY5Y as previously described [27]. SH-SY5Y cells were seeded in a black 96 well plate at $2 \times 10^{4}$ cells/well, incubated for $24 \mathrm{~h}$ and subsequently treated with ESC and DAPH $(20 \mu \mathrm{M})$ for $1-24 \mathrm{~h}$ at $37^{\circ} \mathrm{C}$ in $5 \% \mathrm{CO}_{2}$. At the end of incubation, the treatment medium was discarded and $100 \mu \mathrm{L}$ of the fluorescent probe MCB in PBS (50 $\mu \mathrm{M})$ were added to each well. After $30 \mathrm{~min}$ of incubation at $37^{\circ} \mathrm{C}$, GSH levels were measured (excitation at $355 \mathrm{~nm}$ and emission at $460 \mathrm{~nm}$ ) using the multilabel plate reader VICTOR ${ }^{\text {TM }}$ X3 (PerkinElmer, Waltham, MA, USA). Data are expressed as fold increases versus untreated cells.

\subsection{Nuclear Extraction and Determination of Nrf2 Nuclear Levels}

Nrf2 nuclear levels were evaluated in SH-SY5Y cells as previously described in [28]. SH-SY5Y cells were seeded in $60 \mathrm{~mm}$ dishes at $2 \times 10^{6}$ cells/dish, incubated for $24 \mathrm{~h}$ and subsequently treated with ESC and DAPH $(20 \mu \mathrm{M})$ for 1 and $3 \mathrm{~h}$ at $37{ }^{\circ} \mathrm{C}$ in $5 \% \mathrm{CO}_{2}$. At the end of incubation, nuclear extraction and determination of Nrf2 nuclear levels were performed using Nuclear Extract Kit (Active Motif) and Western blotting, respectively.

The nuclear extracts (50 $\mu \mathrm{g}$ per sample) were separated by $4-15 \%$ SDS polyacrylamide gels and transferred onto nitrocellulose membranes, which were probed with primary Nrf2 antibody (1:1000) and secondary antibody. Enhanced chemiluminescence reagents (Pierce, Rockford, IL, USA) 
were utilized to detect targeted bands. The same membranes were stripped and re-probed with $\beta$-actin and Lamin B1 antibodies Data were analyzed by densitometry, using Quantity One software (Bio-Rad Laboratories S.r.L., Hercules, CA, USA). Data are expressed as fold increases versus untreated cells.

\subsection{Determination of Erk, Akt and GSK3 $\beta$ Protein Phosphorylation}

The phosphorylation of Erk, Akt and GSK3 $\beta$ kinases was evaluated by using the Western blotting method. SH-SY5Y cells were seeded in $60 \mathrm{~mm}$ dishes at $2 \times 10^{6}$ cells/dish, incubated for $24 \mathrm{~h}$ and subsequently treated with $\mathrm{ESC}(20 \mu \mathrm{M})$ for $15,30,60$ and $120 \mathrm{~min}$ at $37{ }^{\circ} \mathrm{C}$ in $5 \% \mathrm{CO}_{2}$. At the end of incubation, cells were trypsinized and the cellular pellet was resuspended in complete lysis buffer containing leupeptin $(2 \mu \mathrm{g} / \mathrm{mL})$, PMSF $(100 \mu \mathrm{g} / \mathrm{mL})$ and cocktail of protease/phosphatase inhibitors $(100 \times)$. Small amounts were removed for the determination of the protein concentration using the Bradford method. The protein lysates (30 $\mu \mathrm{g}$ per sample) were separated by $4-15 \%$ SDS polyacrylamide gels (Bio-Rad Laboratories S.r.L.) and transferred onto $0.45 \mu \mathrm{m}$ nitrocellulose membranes, which were probed with primary phosphorylated antibody p-Erk, p-Akt and p-GSK3 $\beta$ (all 1:1000), and secondary antibodies. ECL reagents (Pierce, Rockford, IL, USA) were utilized to detect targeted bands. The same membranes were stripped using buffer containing $\beta$-mercaptoethanol (18.3 $\mu \mathrm{M})$, SDS (69.35 mM), and Tris. $\mathrm{HCl}(62.5 \mathrm{mM}), \mathrm{pH}$ 6.7, and then re-probed with Erk, Akt and GSK3 $\beta$ antibodies (all 1:1000). Data were analyzed by densitometry, using Quantity One software (Bio-Rad Laboratories S.r.L.). Data are expressed as the ratio between phosphorylated form and total protein expression.

\subsection{0. $A \beta_{1-42}$ oligomer Preparation}

$\mathrm{A} \beta_{1-42}$ peptide was first dissolved in hexafluoroisopropanol to $1 \mathrm{mg} / \mathrm{mL}$, sonicated, incubated at room temperature for $24 \mathrm{~h}$ and lyophilized. The resulting unaggregated $\mathrm{A} \beta_{1-42}$ peptide film was dissolved with dimethyl sulfoxide and stored at $-20^{\circ} \mathrm{C}$ until use. The $\mathrm{A} \beta_{1-42}$ peptide aggregation to oligomeric form was prepared as previously described [29].

\subsection{MTT Formazan Exocytosis Assay}

The neuroprotective activity of ESC against $A \beta_{1-42}$ oligomers was evaluated in SH-SY5Y cells using the MTT formazan exocytosis assay [30]. Briefly, SH-SY5Y cells were seeded in a 96 well plate at $3 \times 10^{4}$ cells/well, incubated for $24 \mathrm{~h}$ and subsequently incubated with ESC $(20 \mu \mathrm{M})$ and OA $\beta_{1-42}$ $(10 \mu \mathrm{M})$ for $4 \mathrm{~h}$ at $37^{\circ} \mathrm{C}$ in $5 \% \mathrm{CO}_{2}$. At the end of incubation, the treatment medium was replaced with MTT in HBSS $(0.5 \mathrm{mg} / \mathrm{mL})$ for $1 \mathrm{~h}$ at $37^{\circ} \mathrm{C}$ in $5 \% \mathrm{CO}_{2}$. Intracellular MTT granules were first solubilized by $1 \%$ Tween 20 at $37^{\circ} \mathrm{C}$ for $10 \mathrm{~min}$ with shaking. Solubilized formazan in the supernatant was then transferred to a new plate as the Tween 20-soluble MTT (TS-MTT). The remaining cell surface needle-like crystals were solubilized with 100\% Isopropanol as the Tween 20-insoluble MTT (TI-MTT). Absorbance values at $590 \mathrm{~nm}$ were determined for each fraction using $630 \mathrm{~nm}$ as the reference wavelength. Data are expressed as percentages with control set at $100 \%$.

\subsection{Determination of ROS Formation Induced by $A \beta_{1-42}$ Oligomers}

To evaluate the antioxidant activity of ESC against ROS formation induced by OA $\beta_{1-42}$, SH-SY5Y cells were seeded in a 96 well plate at $5 \times 10^{3}$ cells/well, incubated for $24 \mathrm{~h}$ and subsequently treated with ESC $(20 \mu \mathrm{M})$ for $24 \mathrm{~h}$ and $\mathrm{A} \beta_{1-42}$ oligomers for $3 \mathrm{~h}$ at $37^{\circ} \mathrm{C}$ in $5 \% \mathrm{CO}_{2}$. At the end of incubation, the treatment was removed and $100 \mu \mathrm{L}$ of the fluorescent probe DHE $(10 \mu \mathrm{M})$ were added to each well. After $30 \mathrm{~min}$ of incubation at $37{ }^{\circ} \mathrm{C}$ in $5 \% \mathrm{CO}_{2}$, the probe DHE was replaced with HBSS and ROS formation was determined using the fluorescence microscope Eclipse Ti-E (Nikon Instruments Spa, Florence, Italy) equipped with TRITC filters (EX 535/50, BS 575, EM 590LP), DS-U3 camera and NIS-Elements BR 3.2 64-bit Software. The intensity of fluorescence was measured from an area corresponding to 20 cells in at least five different random areas. Data are expressed as arbitrary units of fluorescence (AUF). 


\subsection{Determination of Neuronal Death Induced by $A \beta_{1-42}$ Oligomers}

To evaluate the ability of ESC to counteract the neuronal death induced by OA $\beta_{1-42}, \mathrm{SH}-\mathrm{SY} 5 \mathrm{Y}$ cells were seeded in a 96 well plate at $5 \times 10^{3}$ cells/well, incubated for $24 \mathrm{~h}$ and treated with ESC $(20 \mu \mathrm{M})$ and $\mathrm{A} \beta_{1-42}$ oligomers $(10 \mu \mathrm{M})$ for $24 \mathrm{~h}$ at $37^{\circ} \mathrm{C}$ in $5 \%$ of $\mathrm{CO}_{2}$. To evaluate the ability of ESC to prevent the neuronal death induced by OA $\beta_{1-42}$, cells were treated with ESC $(20 \mu \mathrm{M})$ for $24 \mathrm{~h}$ and subsequently with OA $\beta_{1-42}(10 \mu \mathrm{M})$ for $24 \mathrm{~h}$. In parallel, cells were treated with ESC [20 $\mu \mathrm{M}$ ] for $24 \mathrm{~h}$ in the absence or presence of BSO $(400 \mu \mathrm{M})$, PD98059 $(5 \mu \mathrm{M})$ and LY294002 $(10 \mu \mathrm{M})$ and then with OA $\beta_{1-42}(10 \mu \mathrm{M})$ for $24 \mathrm{~h}$. At the end of incubation, the neuronal death was determined using the fluorescent probe PI $(25 \mu \mathrm{g} / \mathrm{mL})$ and the fluorescence microscope Eclipse Ti-E (Nikon Instruments Spa). The total cells were counted in a bright field then only the red dead cells were counted using TRITC filters (EX 535/50, BS 575, EM 590LP). Data are expressed as percentages of dead cells versus total cells.

\subsection{Statistical Analysis}

Data are reported as mean \pm standard deviation (SD) of at least three independent experiments. Statistical analysis was performed using one-way ANOVA with the Dunnett or Bonferroni post-hoc test. Differences were considered significant at $p<0.05$. Analysis was performed using PRISM 5 software (GraphPad Software, La Jolla, CA, USA).

\section{Results and Discussion}

\subsection{Direct and Indirect Antioxidant Activity of Coumarins}

The antioxidant activity of the studied coumarins, in terms of ability to scavenge the free radical, was initially evaluated using ABTS assays and expressed as $\mathrm{IC}_{50}$ (concentration of coumarin able to neutralize $50 \%$ of the ABTS radical). The coumarins were shown to neutralize the ABTS radicals according to the following order of potency: $\mathrm{ESC}\left(\mathrm{IC}_{50}: 2.53 \pm 0.26 \mu \mathrm{M}\right)>\mathrm{DAPH}\left(\mathrm{IC}_{50}: 13.01 \pm 0.10\right.$ $\mu \mathrm{M})>\operatorname{FRAX}\left(\mathrm{IC}_{50}: 14.35 \pm 0.06 \mu \mathrm{M}\right)>\operatorname{SCOP}\left(\mathrm{IC}_{50}: 18.75 \pm 0.26 \mu \mathrm{M}\right)$. ESC, DAPH and FRAX also exerted a similar antioxidant activity against DPPH radical (Figure S1).

In this regard, several studies report that the orto-dihydroxyl (catechol) group and the $\alpha$-pyrone ring present in coumarins ESC, FRAX and DAPH contribute to their radical scavenger and antioxidant activity [31,32]. Other studies also suggest that the number of hydroxyl groups on the ring structure of coumarins is strictly correlated with their antioxidant effects [33]. In agreement with this evidence, SCOP recorded the lowest scavenger activity compared to that of the other studied coumarins.

To evaluate the antioxidant activity of ESC, FRAX, DAPH and SCOP in SH-SY5Y cells, we firstly established the range of coumarin concentrations not associated with neurotoxicity. The treatment of the SH-SY5Y cells with concentrations up to $20 \mu \mathrm{M}$ did not affect neuronal viability using the MTT assay (data not shown). The range of concentrations 5-20 $\mu \mathrm{M}$ was thus selected for all the following experiments. To discriminate the direct and indirect antioxidant activity of the studied coumarins, the SH-SY5Y cells were treated for $2 \mathrm{~h}$ and $24 \mathrm{~h}$ with the respective coumarins, and then treated with $t$-BuOOH, a lipophilic hydroperoxide that shows the ability to generate ROS from lipid peroxidation in brain tissues [34]. At the end of the treatments, the ROS formation was determined using the fluorescent probe DCFH-DA. The treatment of SH-SY5Y cells for $2 \mathrm{~h}$ with 10 and $20 \mu \mathrm{M}$ of ESC, FRAX and DAPH significantly counteracted the ROS formation induced by $t$ - BuOOH $[200 \mu \mathrm{M}]$ for $30 \mathrm{~min}$, while SCOP did not show any antioxidant activity (Figure 2). The ability of ESC, FRAX and DAPH, but not SCOP, to counteract the ROS formation was also significantly correlated to their ability to scavenge the ABTS radical at different concentration levels (ESC: $R^{2}=0.83, p<0.05$; FRAX: $R^{2}=0.93, p<0.01$; DAPH: $\left.R^{2}=0.78, p<0.05\right)$ confirming the contribution of the catechol group to antioxidant effects recorded in SH-SY5Y cells. In contrast to FRAX and SCOP, ESC and DAPH at $20 \mu \mathrm{M}$ also showed the ability to significantly prevent the ROS formation induced by $t$-BuOOH in SH-SY5Y cells after a 24 $\mathrm{h}$ treatment (Figure 3). In a similar experimental approach, shorter treatment (6 and $12 \mathrm{~h}$ ) of SH-SY5Y cells with coumarins did not prevent the ROS formation supporting the indirect antioxidant effects 
recorded after $24 \mathrm{~h}$ treatment, the time necessary to induce a neuronal antioxidant response (data not shown). Taken together, these results indicate that the coumarins with the highest similarity of chemical structure, such as ESC and DAPH, show both direct and indirect antioxidant effects, suggesting a profile of a bifunctional antioxidant. In particular, the direct antioxidant effects of ESC and DAPH in SH-SY5Y cells suggest their ability to counteract the ROS generated from lipid peroxidation in neurons. These results are consistent with recent studies demonstrating that ESC significantly reduced thiobarbituric acid reactive species formation in rat brain homogenates, a well-established method for measuring lipid peroxidation [15,35]. In addition, other studies employed a treatment time of HepG2 liver cells and V79-4 lung fibroblasts with ESC before the treatment with hydrogen peroxide similar to that adopted in our SH-SY5Y cells (i.e., $24 \mathrm{~h}$ ) recording both indirect antioxidant and cytoprotective effects and backing our results [36,37].
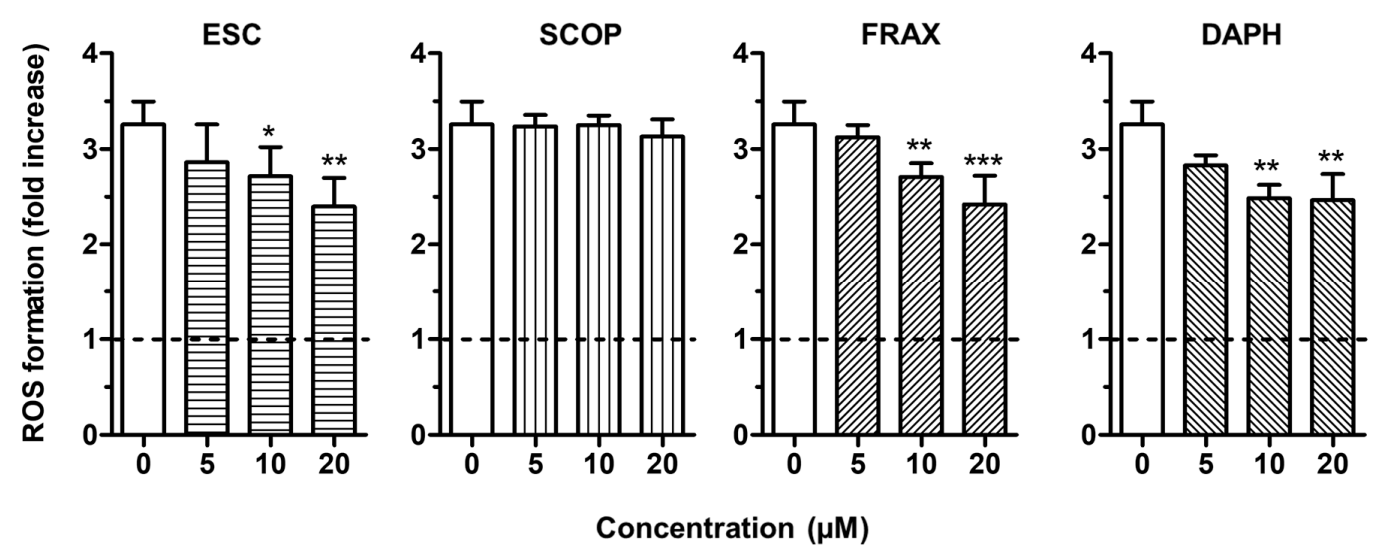

Figure 2. ESC, FRAX and DAPH, but not SCOP, counteract $t$ - $\mathrm{BuOOH}$-induced reactive oxygen species (ROS) formation in SH-SY5Y cells. Cells were treated for $2 \mathrm{~h}$ with various concentrations of the studied coumarins $(5-20 \mu \mathrm{M})$ and then with $t-\mathrm{BuOOH}(200 \mu \mathrm{M})$ for $30 \mathrm{~min}$. At the end of treatment, ROS formation was determined using the fluorescent probe $2^{\prime}, 7^{\prime}$-dichlorodihydrofluorescein diacetate (DCFH-DA). Data are expressed as fold increases of ROS formation induced by $t$-BuOOH and reported as mean $\pm \mathrm{SD}$ of four independent experiments $\left({ }^{*} p<0.05,{ }^{* *} p<0.01\right.$ and ${ }^{* * *} p<0.001$ vs. cells treated with $t$ - $\mathrm{BuOOH}$ at one-way ANOVA with Dunnett post-hoc test).
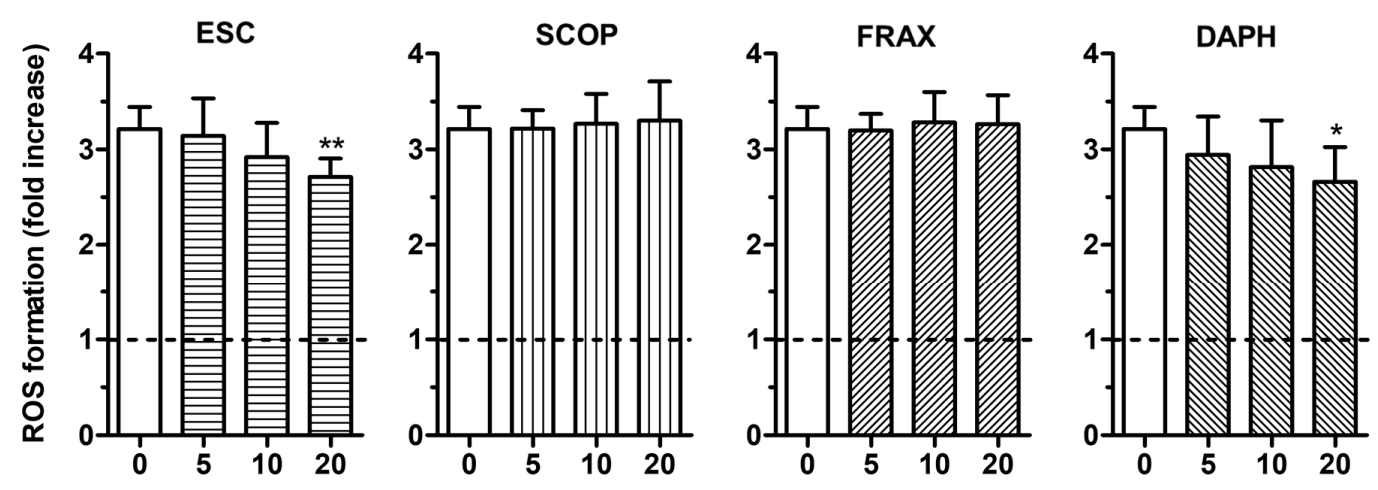

Concentration $(\mu \mathrm{M})$

Figure 3. ESC and DAPH, but not SCOP and FRAX, prevent $t$-BuOOH-induced ROS formation in SH-SY5Y cells. Cells were treated for $24 \mathrm{~h}$ with various concentrations of the studied coumarins $(5-20 \mu \mathrm{M})$ and then with $t$-BuOOH $(200 \mu \mathrm{M})$ for $30 \mathrm{~min}$. At the end of treatment, ROS formation was determined using the fluorescent probe DCFH-DA. Data are expressed as fold increases of ROS formation induced by $t$ - $\mathrm{BuOOH}$ and reported as mean $\pm \mathrm{SD}$ of four independent experiments ${ }^{*} p<$ 0.05 and ${ }^{* *} p<0.01$ vs. cells treated with $t$-BuOOH at one-way ANOVA with Dunnett post-hoc test). 
In order to better evaluate the ability of ESC and DAPH to exert their antioxidant activity at the neuronal level, we measured the TAA, expressed as $\mu \mathrm{mol}$ of trolox equivalent (TE) for mg protein, of cytosolic and membrane-enriched fractions of SH-SY5Y cells treated with $20 \mu \mathrm{M}$ coumarins for $2 \mathrm{~h}$. At the end of incubation, cytosolic and membrane fractions were separated and submitted to the ABTS assay. Both coumarins significantly enhanced the TAA of SH-SY5Y cell cytosol (untreated vs. treated with ESC: $57.15 \pm 7.56$ vs. $88.18 \pm 13.76 \mu \mathrm{mol}$ TE/mg protein, $p<0.05$; untreated vs. treated with DAPH: $88.40 \pm 3.84$ vs. $135.80 \pm 1.19 \mu \mathrm{mol} \mathrm{TE} / \mathrm{mg}$ protein, $p<0.05$ ), while we did not record antioxidant activity in the membrane fraction (data not shown). These results show the ability of ESC and DAPH to cross the cell membrane and reach the cytoplasm where they exert their antioxidant activity. Remarkably, these results also support the ability of ESC to cross complex biological barriers, such as the intestinal barrier and the BBB in various experimental animal models [21,38].

\subsection{Effects of ESC and DAPH on Neuronal Antioxidant Response}

The coumarins ESC and DAPH showed indirect antioxidant effects in terms of ability to prevent ROS formation, suggesting the activation of neuronal antioxidant responses. We thus investigated whether these antioxidant effects might result from an increase in GSH levels and Nrf2 activation, which play key roles in protecting neuronal cells against oxidative stress. In this context, under quiescent conditions, Nrf2 is complexed in the cytoplasm with the Kelch-like ECH-associated protein 1 (Keap1). In conditions of the breakage of this Nrf2/Keap1 complex, Nrf2 translocates into the nucleus and binds to antioxidant response elements (AREs) in the promoter regions of its target genes, like those for GSH synthesis, activating their transcription [10].

The SH-SY5Y cells were incubated for $24 \mathrm{~h}$ with ESC and DAPH [20 $\mu \mathrm{M}]$, and the intracellular GSH levels were then determined using the fluorescent probe MCB. The treatment with ESC, but not DAPH, was shown to significantly increase the GSH levels in SH-SY5Y cells (Figure 4A). In addition, the treatment with ESC $(20 \mu \mathrm{M})$ at increasing times from 1 to $24 \mathrm{~h}$ registered significant decreases in GSH levels after short treatment times ( 1 and $2 \mathrm{~h}$ ) and significant increases in GSH levels after long treatment times (12 and $24 \mathrm{~h}$ ) (Figure 4B).

In parallel, short treatment times of SH-SY5Y cells with ESC and DAPH [20 $\mu \mathrm{M}]$ were also used to evaluate the ability of these coumarins to promote the translocation the Nrf2 into the nucleus and the activation of the Nrf2/ARE binding at this level by Western blotting and ELISA, respectively (Figure 4C,D). Only ESC was shown to significantly increase both the Nrf2 nuclear translocation and Nrf2/ARE binding activity after $1 \mathrm{~h}$ of SH-SY5Y cell treatment. Interestingly, given the known involvement of Nrf2 in the transcriptional induction of GSH, we can state that the early activation of Nrf2 elicited by ESC is prodromal of the late increase in GSH. In this regard, the transient decrease of GSH recorded after short treatment times with ESC suggest that it could activate the Nrf2 through its ability to initially induce a partial GSH depletion and changed redox homeostasis. A recent study indirectly demonstrates that $N$-acetyl-L-cysteine, a precursor of cysteine, restores the degradation of GSH elicited by $1 \mathrm{~h}$ treatment with ESC in Chinese hamster ovary cells supporting the ability of ESC to initially interfere with the GSH redox cycling and the ratio of GSH to oxidized GSH (GSSG) [39]. Although we did not evaluate the activity of enzymes involved in GSH redox cycling, such as GSH reductase and peroxidase, it is probable that this transient decrease of GSH induces the GR activity which recovers and enhances the GSH levels as well as decreasing the GSSG, as previously reported in primary cortical culture and liver from mice [40,41]. In particular, the ESC induced the GR activity without changing the GPx activity, favoring the GSH level.

This particular profile of the biphasic dose-response (i.e., a hormetic response) appears to be involved in the neuroprotection action of several antioxidants that through their ability to perform Michael additions with thiols present on biological molecules including GSH and the Keap-1 negative repressor of Nrf2 [42]. The hydroxyl groups in ESC position six and seven can improve the ability to perform Michael addition more than DAPH position seven and eight. In this context, other in vitro studies in C2C12 myoblasts and HepG2 liver cells support these findings of ESC's ability to protect 
the neuronal cells from oxidative stress through the activation of Nrf2 [36,43]. Remarkably, in a more recent in vivo study, the administration of ESC enhanced the Nrf2 levels and counteracted the mitophagy and mitochondrial apoptosis in hippocampus of mice with cerebral ischemia and reperfusion injury [38].

(A)

(C)
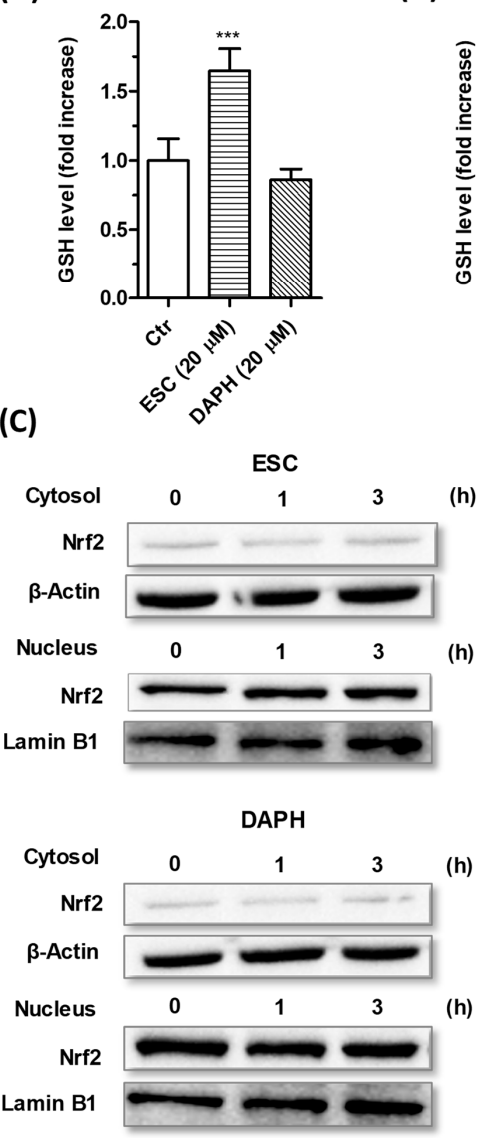

(D)

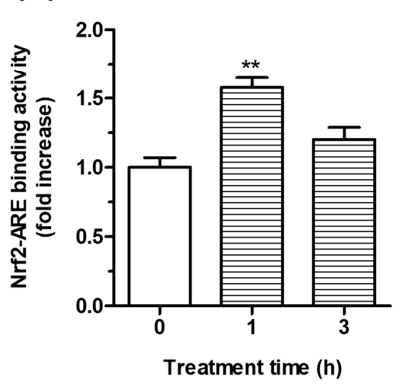

(B)
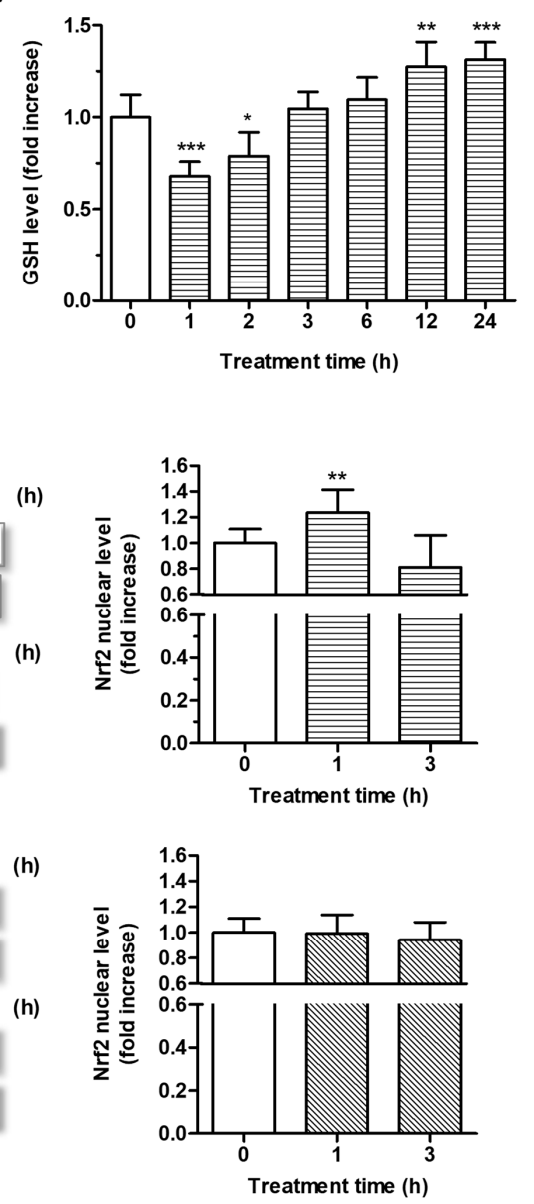

Figure 4. Effects of ESC and DAPH on neuronal antioxidant response in SH-SY5Y cells. (A,B) Cells were treated with ESC and DAPH $(20 \mu \mathrm{M})$ for $24 \mathrm{~h}$ and ESC $(20 \mu \mathrm{M})$ for different times. At the end of treatment, the GSH level was measured using the fluorescent probe MCB. (C) Cells were incubated with ESC and DAPH $(20 \mu \mathrm{M})$ for 1 and $3 \mathrm{~h}$. At the end of incubation, the Nrf2 nuclear level was analyzed by Western blotting. (D) Cells were treated with ESC $(20 \mu \mathrm{M})$ for 1 and $3 \mathrm{~h}$. At the end of treatment, Nrf2-ARE binding activity was determined by ELISA assay. Data are expressed as fold increases and reported as mean $\pm \mathrm{SD}$ of three independent experiments $\left({ }^{*} p<0.05,{ }^{* *} p<0.01\right.$ and ${ }^{* * *} p$ $<0.001$ vs. untreated cells at one-way ANOVA with Dunnett post-hoc test).

\subsection{Neuroprotective Effects of ESC Against A $\beta_{1-42}$ Oligomer-Induced Neuronal Death}

Among the studied coumarins, we selected the coumarin ESC that showed both indirect and direct antioxidant effects to evaluate the neuroprotective effects against the toxicity of $\mathrm{OA} \beta_{1-42}$ using 
the previous experimental approach of treatments of SH-SY5Y cells with ESC. Several studies suggest that $\mathrm{OA} \beta_{1-42}$ adheres to neurons and causes oxidative damage of plasma membrane which initiates a cascade of pathological processes that end with neuronal death [44].

We first evaluated the ability of ESC to counteract the neurotoxic events induced by OA $\beta_{1-42}$. SH-SY5Y cells were treated with ESC $(20 \mu \mathrm{M})$ and OA $\beta_{1-42}(10 \mu \mathrm{M})$ for $24 \mathrm{~h}$ and the neuronal death was then measured using the fluorescent probe PI. The treatment with ESC was shown to significantly decrease the neuronal death evoked by OA $\beta_{1-42}$ (Figure $5 \mathrm{~A}$ ). In parallel, SH-SY5Y cells were treated for $24 \mathrm{~h}$ with ESC $(20 \mu \mathrm{M})$ and then $24 \mathrm{~h}$ with $\mathrm{OA} \beta_{1-42}(10 \mu \mathrm{M})$. At the end of this combined treatment, ESC significantly prevented the neuronal death induced by OA $\beta_{1-42}$ in SH-SY5Y cells (Figure 5B).

(A)

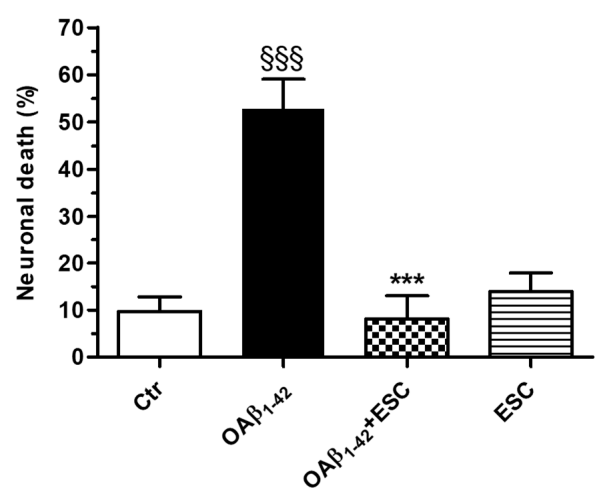

(B)

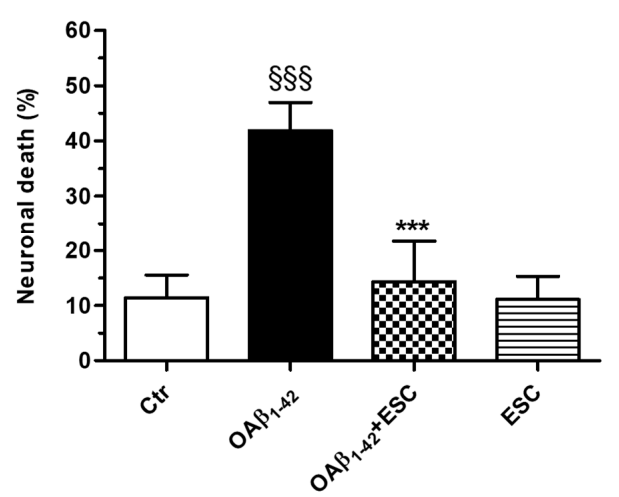

Figure 5. ESC counteracts and prevents the neuronal death induced by OA $\beta_{1-42}$ in SH-SY5Y cells. (A) Cells were treated with ESC $(20 \mu \mathrm{M})$ and OA $\beta_{1-42}(10 \mu \mathrm{M})$ for $24 \mathrm{~h}$. (B) Cells were treated with ESC $(20$ $\mu \mathrm{M})$ for $24 \mathrm{~h}$ and then with $\mathrm{OA} \beta_{1-42}(10 \mu \mathrm{M})$ for $24 \mathrm{~h}$. At the end of treatment, the neuronal death was determined using the fluorescent probe PI. Data are expressed as percentages of dead cells and reported as mean \pm SD of three independent experiments ( $\$ \& \& p<0.001$ vs. untreated cells and ${ }^{* * *} p<0.001$ vs. cells treated with OA $\beta_{1-42}$ at one-way ANOVA with Bonferroni post-hoc test). Scale bars: $100 \mu \mathrm{M}$.

Finally, we investigated the ability of ESC to prevent the OS elicited by OA $\beta_{1-42}$. SH-SY5Y cells were treated for $24 \mathrm{~h}$ with ESC $(20 \mu \mathrm{M})$ and then treated with $\mathrm{OA} \beta_{1-42}(10 \mu \mathrm{M})$ for $3 \mathrm{~h}$. At the end of incubation, the ROS formation was determined using the fluorescent probe DHE. The treatment with ESC was shown to significantly decrease the ROS formation induced by OA $\beta_{1-42}$ (Figure 6).

These results demonstrate for the first time the cytoprotective effects of ESC against the neuronal death evoked by $\mathrm{OA} \beta_{1-42}$. Since recent evidence has demonstrated that ESC lacks chemical properties to inhibit the aggregation of $A \beta_{25-35}$ peptide (the core of the $A \beta_{1-42}$ peptide involved in its aggregation and neurotoxicity), the neuroprotective effects of ESC occurring in concomitant treatment with $\mathrm{OA} \beta_{1-42}$ could be ascribed to independent neuroprotective mechanisms by its interaction with $\mathrm{OA} \beta_{1-42}$ [35]. Recent studies indicate that early mitochondrial impairment in the absence of neuronal death by $\mathrm{OA} \beta_{1-42}$ appears as inhibition of mitochondrial MTT reduction by enhancing MTT formazan exocytosis $[45,46]$. In this regard, we recorded that the concomitant short treatment of SH-SY5Y cells with ESC for $4 \mathrm{~h}$ significantly inhibited the early MTT formazan exocytosis elicited by $\mathrm{OA} \beta_{1-42}$ (Figure S2). In parallel, we also recorded a recovery of intracellular MTT formazan in the same SH-SY5Y cells indicating the neuroprotective effects of ESC on MTT exocytosis (Figure S2B). ESC is therefore likely to counteract early mitochondrial dysfunction mediated by $\mathrm{OA} \beta_{1-42}$ that triggers the subsequent neuronal death. Intriguingly, it was recently demonstrated that the maintenance of both the mitochondrial metabolism and ATP level by "ATP regulators", including ESC, via Estrogen Receptor-Related Receptors also showed a significant neuroprotection in the 1-methyl-4-phenyl-1,2,3,6-tetrahydropyridine and rotenone-induced Parkinson's disease model mice [47]. 
(A)

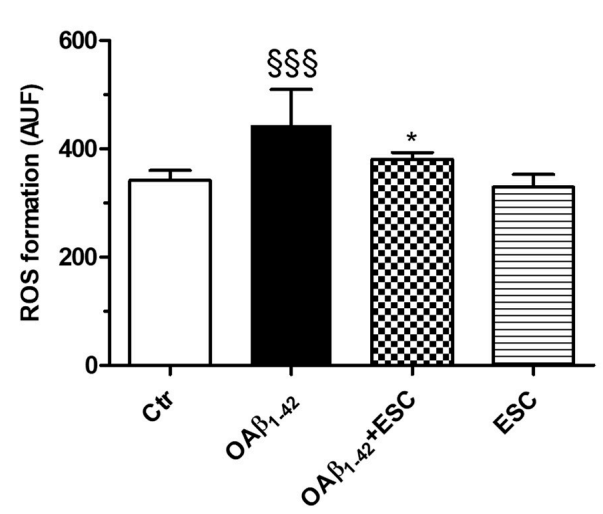

(B)
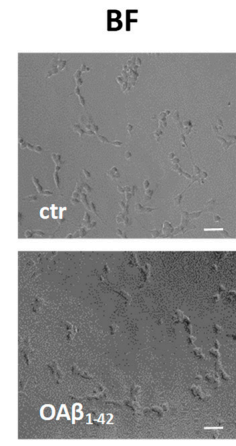

ctr

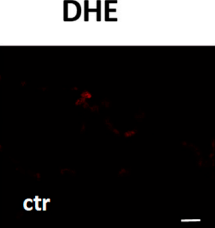

$O A \beta_{1-42}$
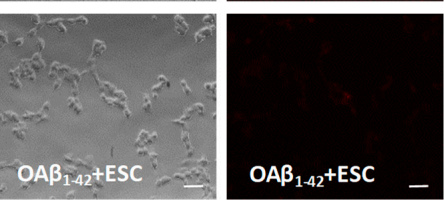

Figure 6. ESC prevents the ROS formation induced by OA $\beta_{1-42}$ in SH-SY5Y cells. (A) Cells were treated with ESC $(20 \mu \mathrm{M})$ for $24 \mathrm{~h}$ and then with OA $\beta_{1-42}(10 \mu \mathrm{M})$ for $3 \mathrm{~h}$. At the end of treatment, the ROS formation was determined using the fluorescent probe DHE. (B) Representative bright field (BF) and DHE fluorescence images. Data are expressed as AUF and reported as mean \pm SD of three independent experiments ( $\$ \S \S p<0.001$ vs. untreated cells, ${ }^{*} p<0.05$ vs. cells treated with OA $\beta_{1-42}$ at one-way ANOVA with Bonferroni post-hoc test). Scale bars: $100 \mu \mathrm{M}$.

\subsection{Effects of ESC on Survival Kinase Pathways}

The ability of ESC to prevent both the ROS formation and neuronal death induced by $\mathrm{OA} \beta_{1-42}$ in SH-SY5Y cells using the same experimental approach of treatment that recorded indirect antioxidant effects and the activation of neuronal antioxidant response suggest that these neuroprotective effects share some upstream signaling pathways. These highlights prompted us to evaluate several kinases, including Erk, Akt and GSK3 $\beta$, involved in both Nrf2 activation and neuronal survival pathways [48].

The phosphorylation of Erk, Akt and GSK3 $\beta$ at Ser9 kinases was determined after different times of treatment $(15,30,60$ and $120 \mathrm{~min})$ of SH-SY5Y cells with ESC $(20 \mu \mathrm{M})$ by Western blotting. The treatment of 15 and 30 min with ESC decreased the phosphorylation of Erk kinase while the treatment of 120 min with ESC increased the phosphorylation of Erk kinase (Figure 7A). In parallel, after $120 \mathrm{~min}$ of treatment with ESC, we also registered an increase of the Akt kinase phosphorylation (Figure 7B). Further, the same treatment was shown to induce the phosphorylation of GSK3 $\beta$ at Ser9, the inactive form (Figure 7C). In contrast to the nuclear activation of Nrf2 in SH-SY5Y cells after $1 \mathrm{~h}$ of treatment with ESC, all the studied kinases showed a significant phosphorylation after $2 \mathrm{~h}$ of treatment, suggesting that these kinases are probably not involved in the upstream activation of Nrf2 or neuronal antioxidant response. However, it is plausible that the activation of these kinases contributes to the neuroprotective effects of ESC only in terms of increasing neuronal survival.

To confirm these observations, we used PD98059 (5 $\mu \mathrm{M})$ and LY294002 [10 $\mu \mathrm{M}]$, inhibitors of Erk and Akt phosphorylation, respectively, during the treatment of SH-SY5Y cells with ESC for $24 \mathrm{~h}$. Cells were then treated for $24 \mathrm{~h}$ with OA $\beta_{1-42}(10 \mu \mathrm{M})$. As shown in Figure 8, the neuroprotective effects of ESC against the OA $\beta_{1-42}$ induced neuronal death were abrogated by using PD98059 and LY294002. In the same experimental conditions, we also recorded similar data using BSO $(400 \mu \mathrm{M})$, an inhibitor of GSH synthesis (Figure 8). 

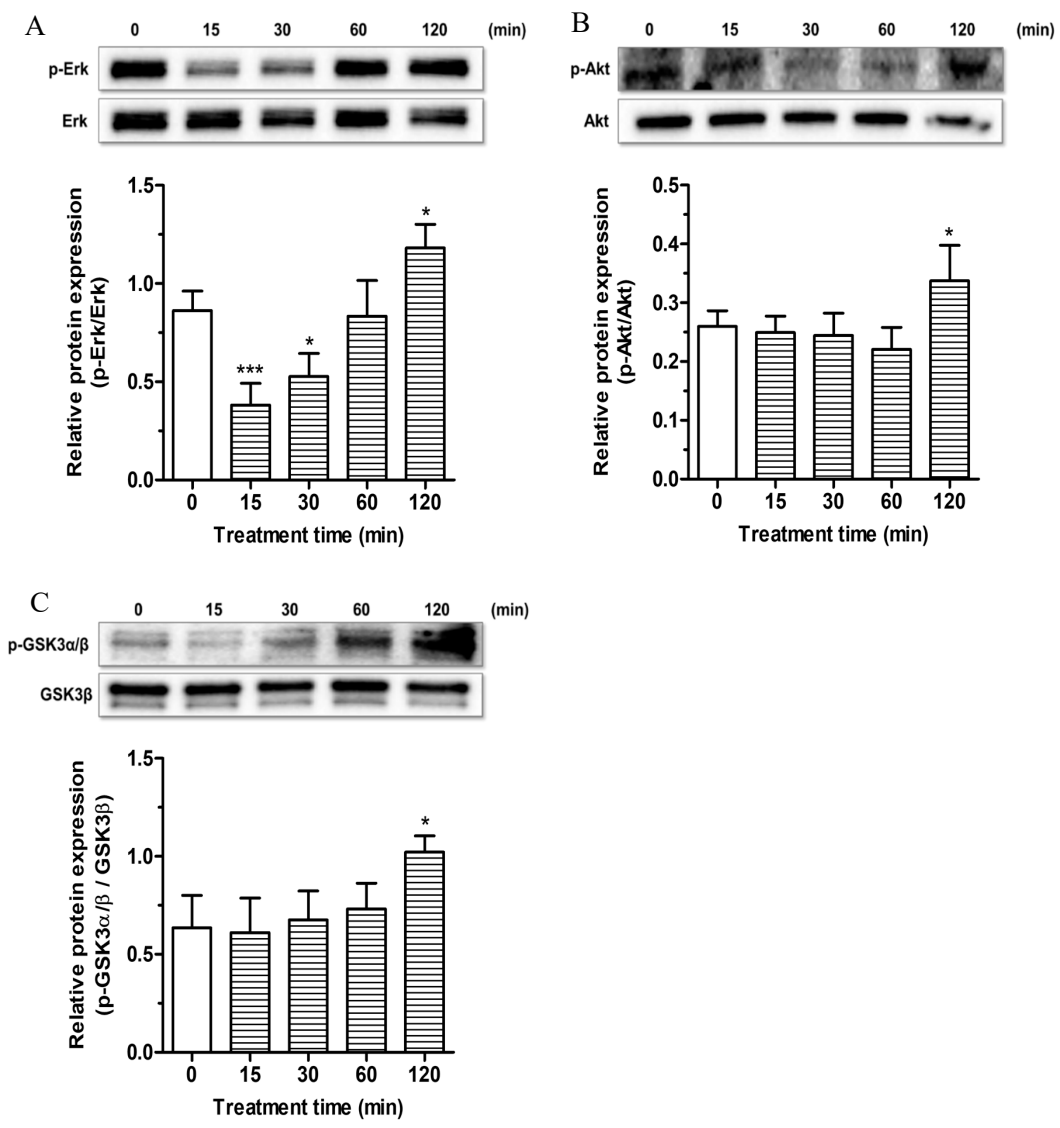

Figure 7. Effects of ESC on survival kinase pathways in SH-SY5Y cells. Cells were treated with ESC (20 $\mu \mathrm{M})$ for different times. At the end of treatment, the phosphorylation of Erk, Akt and GSK3 $\alpha / \beta$ kinase levels was measured by Western blotting. Data are expressed as the ratio between phosphorylated form and total protein expression and reported as mean \pm SD of three independent experiments ( ${ }^{*} p<0.05$ and ${ }^{* * *} p<0.001$ vs. untreated cells at one-way ANOVA with Dunnett post-hoc test).

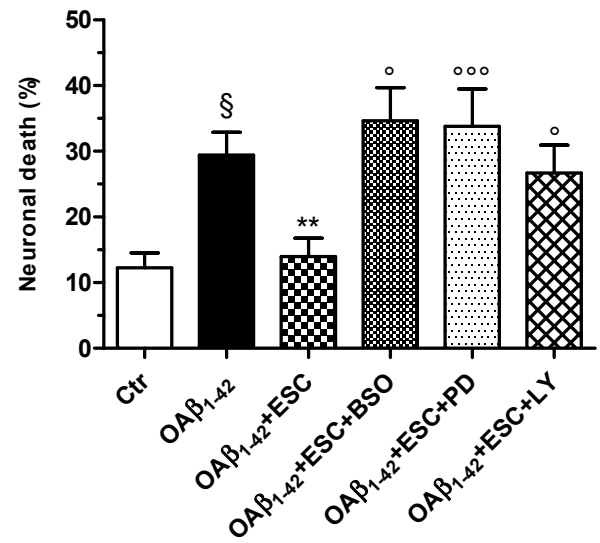

Figure 8. Neuroprotective effects of ESC are abrogated by the specific inhibitors BSO, PD98059 and LY294002 in SH-SY5Y cells. Cells were treated with ESC $(20 \mu \mathrm{M})$ and the specific inhibitors BSO $(400 \mu \mathrm{M})$, PD98059 (5 $\mu \mathrm{M})$ and LY294002 (10 $\mu \mathrm{M})$ for $24 \mathrm{~h}$. Subsequently, cells were treated with $\mathrm{OA} \beta_{1-42}(10 \mu \mathrm{M})$ for $24 \mathrm{~h}$. At the end of treatment, the neuronal death was determined using the fluorescent probe PI. Data are expressed as percentage of dead cells and reported as mean \pm SD of four independent experiments ( $\$ p<0.05$ vs. untreated cells; ${ }^{* *} p<0.01$ vs. cells treated with OA $\beta_{1-42}$; ${ }^{\circ} p<0.05$ and ${ }^{\circ 00} p<0.001$ vs. cells treated with OA $\beta_{1-42}+$ ESC at one-way ANOVA with Bonferroni post-hoc test). 
These results provide significant proof that Erk and Akt signaling pathways are involved in the neuroprotection mediated by ESC. Recent studies showed the ability of ESC to promote cytoprotective effects in $\mathrm{C} 2 \mathrm{C} 12$ myoblasts and human dermal fibroblasts through the phosphorylation of ERK and AKT, respectively, confirming our findings [43,49]. Given the ability of Akt to control glycogen synthesis through phosphorylation and inactivation of GSK3 $\beta$, we can also speculate that the $\mathrm{Akt} / \mathrm{GSK} 3 \beta$ pathway is involved in the neuroprotective action of ESC.

Activation of GSK3 $\beta$ seems to trigger several pathogenic events in $A D$, such as hyper-phosphorylation of tau, increased production of $A \beta$, neuroinflammation and neuronal loss [50].

However, further studies are needed to fully understand the signaling pathways involved in the neuroprotection mediated by ESC. Last, the abolition of the neuroprotective effects of ESC by the inhibition of GSH synthesis also suggests that the induction of GSH at the neuronal level could prove useful as a tool for controlling OS in AD.

\section{Conclusions}

Taken together, these results show the ability of ESC to prevent and counteract OS in SH-SY5Y cells, suggesting its profile of a bifunctional antioxidant. In particular, ESC increases the resistance of the SH-SY5Y cells against OS through the activation of Nrf2 and increase of intracellular GSH. In similar experimental conditions, we further demonstrated that ESC can protect the SH-SY5Y cells from the toxicity evoked by $\mathrm{OA} \beta_{1-42}$. Although we provide a rationale for the use of ESC as an antioxidant in $\mathrm{AD}$, several limits to effective antioxidant treatment must also be considered. In particular, several studies that used compounds with the ability to directly scavenge the ROS recorded poor antioxidant effects as well as conflicting data in human clinical trials probably because they act on complex oxidative events ongoing with other neurodegenerative events [51,52]. However, more research is necessary to evaluate the therapeutic impact of bifunctional antioxidants, including the coumarins, on neurodegenerative processes in human. Several in vitro and in vivo studies on neuroprotection suggest that the compounds with indirect antioxidant activity through the induction of cytoprotective and antioxidant proteins with long half-lives could ensure a long-term action and resolve neurodegenerative processes already in progress [13].

Among the coumarins, ESC also exhibits a potent inhibitory activity against acetylcholinesterase, butyrylcholinesterase and $\beta$-Secretase, advancing its potential profile of multifunctional neuroprotective compound for $\mathrm{AD}$ [53]. Our results therefore encourage further research into AD models to explore the efficacy and safety profile of ESC as a novel neuroprotective agent.

Supplementary Materials: The following are available online at http://www.mdpi.com/2076-3921/9/6/551/s1, Figure S1: DPPH radical-scavenging activity of the studied coumarins, Figure S2: ESC counteracts the early mitochondrial dysfunction induced by OA $\beta_{1-42}$ in SH-SY5Y cells.

Author Contributions: Conceptualization, A.T. and P.H.; investigation, L.P., G.S., F.M.; methodology, L.P.; writing-original draft preparation, L.P.; writing — review and editing, L.P. and A.T.; supervision, A.T.; funding acquisition, A.T. and P.H. All authors have read and agreed to the published version of the manuscript.

Funding: This research was funded by PRIN 2015, grant number 20152HKF3Z and 2015SKN9YT003.

Conflicts of Interest: The authors declare no conflict of interest.

\section{References}

1. Nunomura, A.; Perry, G.; Aliev, G.; Hirai, K.; Takeda, A.; Balraj, E.K.; Jones, P.K.; Ghanbari, H.; Wataya, T.; Shimohama, S.; et al. Oxidative damage is the earliest event in Alzheimer disease. J. Neuropathol. Exp. Neurol. 2001, 60, 759-767. [CrossRef] [PubMed]

2. Meraz-Ríos, M.A.; Franco-Bocanegra, D.; Rios, D.T.; Campos-Peña, V. Early onset Alzheimer's disease and oxidative stress. Oxid. Med. Cell Longev. 2014, 2014, 375968. [CrossRef] [PubMed] 
3. Cervellati, C.; Wood, P.L.; Romani, A.; Valacchi, G.; Squerzanti, M.; Sanz, J.M.; Ortolani, B.; Zuliani, G. Oxidative challenge in Alzheimer's disease: State of knowledge and future needs. J. Investig. Med. 2016, 64, 21-32. [CrossRef]

4. Sutherland, G.T.; Chami, B.; Youssef, P.; Witting, P.K. Oxidative stress in Alzheimer's disease: Primary villain or physiological by-product? Redox Rep. 2013, 18, 134-141. [CrossRef]

5. Cheignon, C.; Tomas, M.; Bonnefont-Rousselot, D.; Faller, P.; Hureau, C.; Collin, F. Oxidative stress and the amyloid beta peptide in Alzheimer's disease. Redox Biol. 2018, 14, 450-464. [CrossRef]

6. Wojsiat, J.; Zoltowska, K.M.; Laskowska-Kaszub, K.; Wojda, U. Oxidant/antioxidant imbalance in Alzheimer's disease: Therapeutic and diagnostic prospects. Oxid. Med. Cell Longev. 2018, 2018, 6435861. [CrossRef]

7. Mandal, P.K.; Saharan, S.; Tripathi, M.; Murari, G. Brain glutathione levels-A novel biomarker for mild cognitive impairment and Alzheimer's disease. Biol. Psychiatry 2015, 78, 702-710. [CrossRef]

8. Chiang, G.C.; Mao, X.; Kang, G.; Chang, E.; Pandya, S.; Vallabhajosula, S.; Isaacson, R.; Ravdin, L.D. Alzheimer's Disease Neuroimaging Initiative; Shungu, D.C. Relationships among cortical glutathione levels, brain amyloidosis, and memory in healthy older adults investigated in vivo with (1)H-MRS and pittsburgh Compound-B PET. AJNR Am. J. Neuroradiol. 2017, 38, 1130-1137. [CrossRef]

9. Prasad, K.N. Simultaneous activation of Nrf2 and elevation of antioxidant compounds for reducing oxidative stress and chronic inflammation in human Alzheimer's disease. Mech. Ageing Dev. 2016, 153, 41-47. [CrossRef]

10. Yang, Y.; Jiang, S.; Yan, J.; Li, Y.; Xin, Z.; Lin, Y.; Qu, Y. An overview of the molecular mechanisms and novel roles of Nrf2 in neurodegenerative disorders. Cytokine Growth Factor Rev. 2015, 26, 47-57. [CrossRef] [PubMed]

11. Zhang, H.; Davies, K.J.A.; Forman, H.J. Oxidative stress response and Nrf2 signaling in aging. Free Radic. Biol. Med. 2015, 88, 314-336. [CrossRef] [PubMed]

12. Burnside, S.W.; Hardingham, G.E. Transcriptional regulators of redox balance and other homeostatic processes with the potential to alter neurodegenerative disease trajectory. Biochem. Soc. Trans. 2017, 45, 1295-1303. [CrossRef] [PubMed]

13. Dinkova-Kostova, A.T.; Talalay, P. Direct and indirect antioxidant properties of inducers of cytoprotective proteins. Mol. Nutr. Food Res. 2008, 52, S128-S138. [CrossRef]

14. Venugopala, K.N.; Rashmi, V.; Odhav, B. Review on natural coumarin lead compounds for their pharmacological activity. Biomed. Res. Int. 2013, 2013, 1-14. [CrossRef]

15. Thuong, P.T.; Hung, T.M.; Ngoc, T.M.; Ha, D.T.; Min, B.S.; Kwack, S.J.; Kang, T.S.; Choi, J.S.; Bae, K. Antioxidant activities of coumarins from Korean medicinal plants and their structure-activity relationships. Phyther. Res. 2010, 24, 101-106. [CrossRef] [PubMed]

16. Kadakol, A.; Sharma, N.; Kulkarni, Y.A.; Gaikwad, A.B. Esculetin: A phytochemical endeavor fortifying effect against non-communicable diseases. Biomed. Pharmacother. 2016, 84, 1442-1448. [CrossRef] [PubMed]

17. Zhu, L.; Nang, C.; Luo, F.; Pan, H.; Zhang, K.; Liu, J.; Zhou, R.; Gao, J.; Chang, X.; He, H.; et al. Esculetin attenuates lipopolysaccharide (LPS)-induced neuroinflammatory processes and depressive-like behavior in mice. Physiol. Behav. 2016, 163, 184-192. [CrossRef]

18. Sulakhiya, K.; Keshavlal, G.P.; Bezbaruah, B.B.; Dwivedi, S.; Gurjar, S.S.; Munde, N.; Jangra, A.; Lahkar, M.; Gogoi, R. Lipopolysaccharide induced anxiety- and depressive-like behaviour in mice are prevented by chronic pre-treatment of esculetin. Neurosci. Lett. 2016, 611, 106-111. [CrossRef]

19. Martín-Aragón, S.; Villar, Á.; Benedí, J. Age-dependent effects of esculetin on mood-related behavior and cognition from stressed mice are associated with restoring brain antioxidant status. Prog. Neuropsychopharmacol. Biol. Psychiatry 2016, 65, 1-16.

20. Wang, C.; Pei, A.; Chen, J.; Yu, H.; Sun, M.L.; Liu, C.F.; Xu, X. A natural coumarin derivative esculetin offers neuroprotection on cerebral ischemia/reperfusion injury in mice. J. Neurochem. 2012, 121, 1007-1013. [CrossRef]

21. Subramaniam, S.R.; Ellis, E.M. Neuroprotective effects of umbelliferone and esculetin in a mouse model of Parkinson's disease. J. Neurosci. Res. 2013, 91, 453-461. [CrossRef] [PubMed]

22. Rampa, A.; Bartolini, M.; Pruccoli, L.; Naldi, M.; Iriepa, I.; Moraleda, I.; Belluti, F.; Gobbi, S.; Tarozzi, A.; Bisi, A. Exploiting the chalcone scaffold to develop multifunctional agents for Alzheimer's disease. Molecules 2018, 23, 1902. [CrossRef] [PubMed] 
23. Rampa, A.; Tarozzi, A.; Mancini, F.; Pruccoli, L.; Di Martino, R.M.C.; Gobbi, S.; Bisi, A.; De Simone, A.; Palomba, F.; Zaccheroni, N.; et al. Naturally inspired molecules as multifunctional agents for Alzheimer's disease treatment. Molecules 2016, 21, 643. [CrossRef] [PubMed]

24. Rampa, A.; Montanari, S.; Pruccoli, L.; Bartolini, M.; Falchi, F.; Feoli, A.; Cavalli, A.; Belluti, F.; Gobbi, S.; Tarozzi, A.; et al. Chalcone-based carbamates for Alzheimer's disease treatment. Future Med. Chem. 2017, 9, 533-536. [CrossRef]

25. Montanari, S.; Bartolini, M.; Neviani, P.; Belluti, F.; Gobbi, S.; Pruccoli, L.; Tarozzi, A.; Falchi, F.; Andrisano, V.; Miszta, P.; et al. Multitarget strategy to address Alzheimer's disease: Design, synthesis, biological evaluation, and computational studies of coumarin-based derivatives. ChemMedChem 2016, 11, 1296-1308. [CrossRef]

26. Tarozzi, A.; Morroni, F.; Hrelia, S.; Angeloni, C.; Marchesi, A.; Cantelli-Forti, G.; Hrelia, P. Neuroprotective effects of anthocyanins and their in vivo metabolites in SH-SY5Y cells. Neurosci. Lett. 2007, 424, 36-40. [CrossRef]

27. Sestito, S.; Pruccoli, L.; Runfola, M.; Citi, V.; Martelli, A.; Saccomanni, G.; Calderone, V.; Tarozzi, A.; Rapposelli, S. Design and synthesis of H(2)S-donor hybrids: A new treatment for Alzheimer's disease? Eur. J. Med. Chem. 2019, 184, 111745. [CrossRef]

28. Morroni, F.; Sita, G.; Djemil, A.; D’Amico, M.; Pruccoli, L.; Cantelli-forti, G.; Hrelia, P.; Tarozzi, A. Comparison of adaptive neuroprotective mechanisms of sulforaphane and its interconversion product erucin in in vitro and in vivo models of Parkinson's disease. J. Agric. Food Chem. 2018, 66, 856-865. [CrossRef]

29. Tarozzi, A.; Bartolini, M.; Piazzi, L.; Valgimigli, L.; Amorati, R.; Bolondi, C.; Djemil, A.; Mancini, F.; Andrisano, V.; Rampa, A. From the dual function lead AP2238 to AP2469, a multi-target-directed ligand for the treatment of Alzheimer's disease. Pharmacol. Res. Perspect. 2014, 2, e00023. [CrossRef]

30. Kreutzmann, P.; Wolf, G.; Kupsch, K. Minocycline recovers MTT-formazan exocytosis impaired by amyloid beta peptide. Cell. Mol. Neurobiol. 2010, 30, 979-984. [CrossRef]

31. Kaneko, T.; Baba, N.; Matsuo, M. Protection of coumarins against linoleic acid hydroperoxide induced cytotoxicity. Chem. Biol. Interact. 2003, 142, 239-254. [CrossRef]

32. Wu, C.R.; Huang, M.Y.; Lin, Y.T.; Ju, H.Y.; Ching, H. Antioxidant properties of Cortex Fraxini and its simple coumarins. Food Chem. 2007, 104, 1464-1471. [CrossRef]

33. Veselinović, J.B.; Veselinović, A.M.; Vitnik, Ž.J.; Vitnik, V.D.; Nikolić, G.M. Antioxidant properties of selected 4-phenyl hydroxycoumarins: Integrated in vitro and computational studies. Chem. Biol. Interact. 2014, 214, 49-56. [CrossRef] [PubMed]

34. Bano, S.; Parihar, M.S. Reduction of lipid peroxidation in different brain regions by a combination of alpha-tocopherol and ascorbic acid. J. Neural Transm. 1997, 104, 1277-1286. [CrossRef]

35. Seong, S.H.; Ali, M.Y.; Jung, H.A.; Choi, J.S. Umbelliferone derivatives exert neuroprotective effects by inhibiting monoamine oxidase A, self-amyloid $\beta$ aggregation, and lipid peroxidation. Bioorg. Chem. 2019, 92, 103293. [CrossRef] [PubMed]

36. Subramaniam, S.R.; Ellis, E.M. Esculetin-induced protection of human hepatoma HepG2 cells against hydrogen peroxide is associated with the Nrf2-dependent induction of the NAD(P)H: Quinone oxidoreductase 1 gene. Toxicol. Appl. Pharmacol. 2011, 250, 130-136. [CrossRef]

37. Kim, S.H.; Kang, K.A.; Zhang, R.; Piao, M.J.; Ko, D.O.; Wang, Z.H.; Kang, S.S.; Lee, K.H.; Kang, H.K.; Kang, H.W.; et al. Protective effect of esculetin against oxidative stress-induced cell damage via scavenging reactive oxygen species. Acta Pharmacol. Sin. 2008, 29, 1319-1326. [CrossRef]

38. Xu, B.; Zhu, L.; Chu, J.; Ma, Z.; Fu, Q.; Wei, W.; Deng, X.; Ma, S. Esculetin improves cognitive impairments induced by transient cerebral ischaemia and reperfusion in mice via regulation of mitochondrial fragmentation and mitophagy. Behav. Brain Res. 2019, 372, 112007. [CrossRef]

39. Shinde, R.G.; Khan, A.A.; Kunwar, A.; Tripathi, V.S.; Barik, A. Fluorescence "off" and "on" signalling of esculetin in the presence of copper and thiol: A possible implication in cellular thiol sensing. Photochem. Photobiol. Sci. 2018, 17, 1197-1205. [CrossRef]

40. Lee, C.R.; Shin, E.J.; Kim, H.C.; Choi, Y.S.; Shin, T.; Wie, M.B. Esculetin inhibits N-methyl-D-aspartate neurotoxicity via glutathione preservation in primary cortical cultures. Lab. Anim. Res. 2011, 27, 259-263. [CrossRef]

41. Martin-Aragón, S.; Benedi, J.M.; Villar, A.M. Effects of the antioxidant (6,7-dihydroxycoumarin) esculetin on the glutathione system and lipid peroxidation in mice. Gerontology 1998, 44, 21-25. [CrossRef] [PubMed] 
42. Calabrese, E.J.; Calabrese, V.; Giordano, J. The role of hormesis in the functional performance and protection of neural systems. Brain Circ. 2017, 3, 1-13. [PubMed]

43. Han, M.H.; Park, C.; Lee, D.S.; Hong, S.H.; Choi, I.W.; Kim, G.Y.; Choi, S.H.; Shim, J.H.; Chae, J.I.; Yoo, Y.H.; et al. Cytoprotective effects of esculetin against oxidative stress are associated with the upregulation of Nrf2-mediated NQO1 expression via the activation of the ERK pathway. Int. J. Mol. Med. 2017, 39, 380-386. [CrossRef] [PubMed]

44. Tarozzi, A.; Morroni, F.; Merlicco, A.; Bolondi, C.; Teti, G.; Falconi, M.; Cantelli-Forti, G.; Hrelia, P. Neuroprotective effects of cyanidin 3-O-glucopyranoside on amyloid beta (25-35) oligomer-induced toxicity. Neurosci. Lett. 2010, 473, 72-76. [CrossRef]

45. Liu, M.L.; Hong, S.T. Early phase of amyloid beta42-induced cytotoxicity in neuronal cells is associated with vacuole formation and enhancement of exocytosis. Exp. Mol. Med. 2005, 37, 559-566. [CrossRef]

46. Hong, H.S.; Maezawa, I.; Yao, N.; Xu, B.; Diaz-Avalos, R.; Rana, S.; Hua, D.H.; Cheng, R.H.; Lam, K.S.; Jin, L.W. Combining the rapid MTT formazan exocytosis assay and the MC65 protection assay led to the discovery of carbazole analogs as small molecule inhibitors of A $\beta$ oligomer-induced cytotoxicity. Brain Res. 2007, 1130, 223-234. [CrossRef]

47. Nakano, M.; Imamura, H.; Sasaoka, N.; Yamamoto, M.; Uemura, N.; Shudo, T.; Fuchigami, T.; Takahashi, R.; Kakizuka, A. ATP maintenance via two types of ATP regulators mitigates pathological phenotypes in mouse models of Parkinson's disease. EBioMedicine 2017, 22, 225-241. [CrossRef]

48. Bryan, H.K.; Olayanju, A.; Goldring, C.E.; Park, B.K. The Nrf2 cell defence pathway: Keap1-dependent and -independent mechanisms of regulation. Biochem. Pharmacol. 2013, 85, 705-717. [CrossRef]

49. Park, J.H.; Kim, S.R.; An, H.J.; Kim, W.J.; Choe, M.; Han, J.A. Esculetin promotes type I procollagen expression in human dermal fibroblasts through MAPK and PI3K/Akt pathways. Mol. Cell. Biochem. 2012, 368, 61-67. [CrossRef]

50. Kitagishi, Y.; Nakanishi, A.; Ogura, Y.; Matsuda, S. Dietary regulation of PI3K/AKT/GSK-3 $\beta$ pathway in Alzheimer's disease. Alzheimers Res. Ther. 2014, 6, 35. [CrossRef]

51. Pitchumoni, S.S.; Doraiswamy, P.M. Current status of antioxidant therapy for Alzheimer's Disease. J. Am. Geriatr. Soc. 1998, 46, 1566-1572. [CrossRef] [PubMed]

52. LLoret, A.; Giraldo, E.; Viña, J. Is antioxidant therapy effective to treat alzheimer's disease? Free Rad. Antiox. 2011, 1, 8-14. [CrossRef]

53. Ali, M.Y.; Jannat, S.; Jung, H.A.; Choi, R.J.; Roy, A.; Choi, J.S. Anti-Alzheimer's disease potential of coumarins from Angelica decursiva and Artemisia capillaris and structure-activity analysis. Asian Pac. J. Trop. Med. 2016, 9, 103-111. [CrossRef] [PubMed]

(C) 2020 by the authors. Licensee MDPI, Basel, Switzerland. This article is an open access article distributed under the terms and conditions of the Creative Commons Attribution (CC BY) license (http://creativecommons.org/licenses/by/4.0/). 